\title{
Energetic flux and performance index in copaiba (Copaifera multijuga Hayne) and mahogany (Swietenia macrophylla King) seedlings grown under two irradiance environments
}

\author{
José F.C. Gonçalves*, Ulysses M. Santos Jr., Adamir R. Nina Jr. and Larissa R. Chevreuil \\ Instituto Nacional de Pesquisas da Amazônia, Laboratório de Fisiologia e Bioquímica Vegetal, Caixa Postal 478, \\ 69011-970 Manaus, AM, Brasil. *Corresponding author: jfc@inpa.gov.br. Phone: +55 92 3643-1938, Fax: +55 92 \\ 36431838
}

Received: 06 July 2007; Returned for revision: 05 September 2007; Accepted: 27 October 2007

Plant adaptation under conditions of limited irradiance can be investigated by their efficiency while using the available energy with a minimal thermodynamic energy loss. For this reason, we compared the energetic fluxes and the performance index $\left(\mathrm{PI}_{\mathrm{ABS}}\right.$ ) in copaiba (Copaifera multijuga) and mahogany (Swietenia macrophyla) seedlings under both sunlight and shade. The experiment was carried out in Manaus (38'S, 5952’W), Amazonas State, Brazil. The fluorescence transients were obtained in intact and healthy leaves using a Plant Efficiency Analyser (PEA) between $1200 \mathrm{~h}$ and $1300 \mathrm{~h}$. Using the O-J-I-P test, the following parameters were calculated: 1) density of reaction centers per cross section (RC/CS), 2) maximum quantum yield for primary photochemistry of photosystem II ( $\varphi_{\mathrm{P}_{0}}$ ), and 3 ) probability of energy excitation $\left(\psi_{0}\right)$ or that of an absorbed photon $\left(\varphi_{E_{0}}\right)$ to move an electron further than quinone $A$, and 4$)$ the performance index $\left(\mathrm{PI}_{\mathrm{ABS}}\right)$. The highest $\mathrm{PI}_{\mathrm{ABS}}$ was found in seedlings under shade for both species. Mahogany seedlings exhibited values of $\mathrm{PI}_{\mathrm{ABS}}$ about three-fold and 14-fold higher than copaiba seedlings under shade and sunlight, respectively. For RC/CS, reaction centers were inactive under sunlight, $58 \%$ for mahogany and $78 \%$ for copaiba. The high irradiance induced a decrease of $\varphi_{\mathrm{P}_{\mathrm{p}}}$ in mahogany (36\%) and in copaiba (69\%) when compared to shaded seedlings. This likely was a result of need for excess energy dissipation under sunlight. In addition, it was verified that seedlings under sunlight presented a severe decrease in $\varphi_{\mathrm{E}}$, particularly in copaiba (23-fold), when compared to mahogany (9fold). Therefore, mahogany seedlings showed the highest performance in energy use under low and high irradiance, thus it may be proposed that mahogany presented lower entropy than copaiba seedlings, as demonstrated by the higher plasticity in the use of energy.

Key words: chlorophyll $a$ fluorescence, energy fluxes in photosystem II, light acclimation, O-J-I-P transients, tropical tree species

Fluxo energético e índice de desempenho em plantas jovens de copaíba (Copaifera multijuga) e de mogno (Swietenia macrophyla) sob dois ambientes de irradiância: Adaptação de plantas sob condições limitantes de irradiância pode ser investigada pela eficiência do uso da energia disponível, com uma perda mínima da energia termodinâmica. Por essa razão, foram comparados o fluxo energético e o índice de desempenho ( $\mathrm{PI}_{\mathrm{ABS}}$ ) em plantas jovens de copaíba (Copaifera multijuga) e de mogno (Swietenia macrophyla) sob condições de sol e sombra. O experimento foi conduzido em Manaus (38'S, 5952'W). Os transientes de fluorescência foram obtidos em folhas saudáveis e intactas, utilizando-se de um fluorômetro portátil, no período entre 1200 e 1300 h. A partir do teste O-J-I-P foram calculados os seguintes parâmetros: 1) densidade de centros de reação por seção transversal (RC/CS), 2) eficiência máxima do fotossistema II $\left.\left(\varphi_{\mathrm{P}_{0}}\right), 3\right)$ probabilidade da energia de excitação $\left(\psi_{\mathrm{o}}\right)$ ou de um fóton absorvido $\left(\varphi_{\mathrm{Eo}}\right)$ mover um elétron após a quinoma $\mathrm{A}$, 
e 4) índice de desempenho ( $\mathrm{PI}_{\mathrm{ABS}}$ ). Os maiores valores de $\mathrm{PI}_{\mathrm{ABS}}$ foram encontrados em plantas jovens sob sombra, para ambas as espécies. Plantas de mogno exibiram valores de $\mathrm{PI}_{\mathrm{ABS}}$ cerca de três vezes e 14 vezes maiores que os de plantas de copaíba sob condições de sombra e sol, respectivamente. Para RC/CS foi observado que 58\% e 78\% dos centros de reação em mogno e em copaíba, respectivamente, foram inativados sob condições de sol. Alta irradiância induziu decréscimos em $\varphi_{\mathrm{P}_{0}}$ em mogno (36\%) e em copaiba (69\%) quando comparado com as plantas à sombra, resultado da necessidade de dissipação do excesso de energia sob plena exposição solar. Verificou-se também que plantas sob sol apresentaram decréscimo severo em $\varphi_{\text {Eo }}$, particularmente em copaíba (23 vezes) quando comparado com mogno (nove vezes). Portanto, plantas jovens de mogno exibiram os mais altos índices de desempenho sob baixas e altas irradiâncias, o quê sugere menor entropia do que em plantas jovens de copaíba, além de demonstrar maior plasticidade para o uso da energia.

Palavras-chave: aclimatação à irradiância; espécies arbóreas tropicais, fluorescência da clorofila $a$, fluxos de energia no fotossistema II, transients O-J-I-P

\section{INTRODUCTION}

Forest environment presents high heterogeneity in terms of light availability, both spatially (forest layers, forest understorey, sub-canopy environments and high gaps) and temporally (seasonal periods). Besides such heterogeneity, human activities (extensive deforestation) and/or natural events can promote frequent and significant changes in balanced environments, thus the establishment of a species and/or its continuity in the system are functions of its capacity to adapt its metabolism to the new environmental conditions (Kruger et al., 1997; Gonçalves and Santos Jr., 2005a). Irradiance availability is the basic factor for the energy flux in biological systems, largely determining the physiological processes of plants. Depending on the capture and use capacity of irradiance, plants present different and decisive responses for their survival, growth and adaptation under different light conditions. For this reason, shaded or full sunlight environments can inhibit the photosynthetic processes either because of shortage or of excess energy input (Zhang et al., 2003). In this way, the capacity of plants in adjusting their metabolism to optimize the use of primary resources such as light will determine the success or failure of their adaptation and establishment under given conditions of irradiance.

The chlorophyll a fluorescence technique is of particular significance in natural environments to study how the irradiance availability affects the tree photosynthetic apparatus and its efficiency under different light conditions (Gonçalves et al., 2001, 2005; Gonçalves and Santos Jr., 2005b; Santos Jr. et al., 2006). The analysis of chlorophyll $a$ fluorescence emitted by
PSII is a fast, easy, and non-invasive tool to evaluate the plant's photosynthetic performance, providing precise and objective data with regard to photochemical efficiency and the processes of non-photochemical deexcitation involved in the conversion of light energy under different conditions (Clark et al., 2000; Misra et al., 2001; Baker and Rosenqvist, 2004; De Ronde et al., 2004; Gonçalves and Santos Jr., 2005b; Panda et al., 2006). The PSII unit catalyses the light-induced electron transport from water to the plastoquinone (PQ) pool molecule and consists of up to 25 different types of protein subunits, which are organized into two structurally and functionally different parts (Hankamer et al., 1997; Stirbet et al., 1998). The first part is the core complex, a well-defined structure responsible for all electron transfer reactions in PSII and organized as a dimer in the stacked, appressed regions of the thylakoid membrane. The second part is the peripheral antenna; in plants it consists of a collection of light-harvesting complex II (LHCII) proteins which absorb most of the light for PSII (Dekker and Grondelle, 2000). Under conditions of high irradiance, PSII is recognizably the first protein complex to exhibit damage. For this reason, a study of the structural and functional behavior of PSII can allow the examination of the primary effects of stress caused by excess irradiance on plants.

In this study, two species found in the primary Amazonian forest, mahogany (Meliaceae) and copaiba (Leguminosae: Caesalpinioideae), were compared to investigate interspecific variations in chlorophyll $a$ fluorescence. Mahogany is one of the most valuable neotropical timber species in tropical forests (Whitman et 
al., 1997) whereas copaiba has been traditionally and widely used as oil or capsules that have been exported from Brazil to other countries such as France, Germany and United States (Veiga and Pinto, 2001; Veiga et al., 2001). The main goal of this study was to evaluate the efficiency in capture and use of light energy and the performance index in environments of low and high irradiance through the analysis of changes in the shape of O-J-I-P transients, the parameters of chlorophyll $a$ fluorescence and the performance index $\left(\mathrm{PI}_{\mathrm{ABS}}\right)$ in those species.

\section{MATERIAL AND METHODS}

Study area and species investigated: This study was conducted in the experimental area of the V-8 Campus at the Instituto Nacional de Pesquisas da Amazônia, Manaus (38'S, 5958’W), Amazonas State, Brazil. The experiment was carried out using eight-month-old mahogany (Swietenia macrophyla King) and copaiba (Copaifera multijuga Hayne) seedlings. Seedlings were obtained from seeds collected in the Adolfo Ducke Forest Reservation, located $10 \mathrm{~km}$ from the city of Manaus. Seeds were selected according to their uniformity, size and healthy state. After disinfections in sodium hypochlorite solution $1 \%$ chlorine (v/v) for $10 \mathrm{~min}$, seeds were washed in running tap water and then in distilled water. Afterwards, they were placed to germinate in plastic boxes filled with washed sand as substrate. After reaching a height of $10 \mathrm{~cm}$, the seedlings were transferred to black polyethylene bags containing $5 \mathrm{~kg}$ of an organic soil and sand mixture (2:1, w/w), where they remained for $30 \mathrm{~d}$ for acclimatization. The seedlings were grown under mid-intensity irradiance (maximum irradiance $=250-500$ $\mu \mathrm{mol} \mathrm{m} \mathrm{m}^{-2} \mathrm{~s}^{-1}$ ) until reaching eight months old. Afterwards they were assigned to two light treatments: shade, maximum irradiance $=10-30 \mu \mathrm{mol} \mathrm{m} \mathrm{m}^{-2} \mathrm{~s}^{-1}$, and sunlight, maximum irradiance $=1800-2300 \mu \mathrm{mol} \mathrm{m} \mathrm{m}^{-2} \mathrm{~s}^{-1}$, under natural day/night cycles of about 12-13/12-11 h. During the experiment, plants were watered daily. The data were collected after $120 \mathrm{~d}$ of the experiment when the young leaves growing in the new environment were fully expanded.

Measurements of Chlorophyll a fluorescence: The chlorophyll $a$ fluorescence was measured in healthy and completely expanded leaves using a hand fluorometer
(Plant Efficiency Analyser-MK2-9600, Hansatech, Norfolk, UK). Measurements were taken between 1200 and $1300 \mathrm{~h}$ using 10 plants per species per irradiance level. The selected leaves were subjected to a $20 \mathrm{~min}$ dark-adaptation period, a period of time sufficient for all reaction centers of PSII to become open (Rhee et al., 1998; Zouni et al., 2001). Immediately after the dark adaptation, the leaves were exposed to a pulse of saturating light at an intensity of $2700 \mu \mathrm{mol} \mathrm{m} \mathrm{m}^{-2} \mathrm{~s}^{-1}$, with a wavelength of $650 \mathrm{~nm}$ for $5 \mathrm{~s}$. The fluorescence transients were recorded from $10 \mu \mathrm{s}$ to $5 \mathrm{~s}$ at 12 bit resolution (Strasser et al., 2000). The Biolyzer software (MaldonadoRodríguez, 2000) was used to load the full fluorescence transients and to calculate the O-J-I-P parameters from variable fluorescence values at $\mathrm{F}_{50 \mu \mathrm{s}}, \mathrm{F}_{100 \mu \mathrm{s}}, \mathrm{F}_{300 \mu \mathrm{s}}, \mathrm{F}_{2 \mathrm{~ms}}$ and $\mathrm{F}_{30 \mathrm{~ms}}$, according to the equations of the O-J-I-P-test (Strasser and Govindjee, 1992; Strasser and TsimilliMichael, 2001) (see Table 1 for further details). The specific fluxes expressed per reaction centers (ABS/RC; $\mathrm{TR}_{\mathrm{O}} / \mathrm{RC} ; \mathrm{DI}_{\mathrm{O}} / \mathrm{RC} \mathrm{ET}_{\mathrm{O}} / \mathrm{RC}$ ) and phenomenological fluxes per cross section (ABS/CS; $\mathrm{TR}_{\mathrm{O}} / \mathrm{CS} ; \mathrm{DI}_{\mathrm{O}} / \mathrm{CS} ; \mathrm{ET}_{\mathrm{O}} / \mathrm{CS}$ ) were derived from the theory of energy flux from biomembranes (Sironval et al., 1981) and were calculated using the O-J-I-P test (Strasser and Tsimilli-Michael, 2001). Absorbance (ABS) refers to the absorption of photons by the chlorophyll molecules in the antenna complex. Part of the absorbed energy was trapped $\left(\mathrm{TR}_{\mathrm{O}}\right)$ by the reaction centre of PSII $\left(\mathrm{P}_{680}\right)$ while the remainder was dissipated $\left(\mathrm{DI}_{\mathrm{O}}\right)$ in the form of heat and fluorescence. Of the trapped energy, part of it was converted to redox energy by electron transport $\left(\mathrm{ET}_{\mathrm{O}}\right)$ through $\mathrm{Q}_{\mathrm{A}}$ and $\mathrm{Q}_{\mathrm{B}}$ (Strasser et al., 2000). Furthermore, the following variables were determined: the density of reaction centers (RC) per cross section (RC/CS), the maximum quantum efficiency of PSII primary photochemistry $\left(\varphi_{\mathrm{Po}_{\mathrm{o}}}=\right.$ $\mathrm{TR}_{\mathrm{O}} / \mathrm{ABS}$ ), the maximum efficiency of non-photochemical de-excitation $\left(\varphi_{\mathrm{P}_{\mathrm{o}}}=\mathrm{DI}_{\mathrm{O}} / \mathrm{ABS}\right)$ and, the probability that a trapped exciton $\left(\psi_{0}=\mathrm{ET}_{\mathrm{O}} / \mathrm{TR}_{\mathrm{O}}\right)$ or that an absorbed photon $\left(\varphi_{\mathrm{Eo}}=\mathrm{ET}_{\mathrm{O}} / \mathrm{ABS}\right)$ moves an electron further than quinone $A\left(Q_{A}\right)$. The performance index (PI) has been defined as the ratio of two structure-function indexes (SFI). The first, $\mathrm{SFI}_{\mathrm{Po}(\mathrm{ABS})}\left(\left(\mathrm{Chl}_{\mathrm{RC}} / \mathrm{Chl}_{\mathrm{tot}}\right) \times \varphi_{\mathrm{Po}_{\mathrm{o}}} \times \psi_{\mathrm{o}}\right)$, responds to structural and functional PSII events leading to electron transport within photosynthesis (TsmilliMichael et al., 1998). The second, $\mathrm{SFI}_{\mathrm{No}(\mathrm{ABS})}\left(\left[1-\left(\mathrm{Chl}_{\mathrm{RC}}{ }^{\prime}\right.\right.\right.$ $\left.\left.\left.\mathrm{Chl}_{\text {tot }}\right)\right]\left(1-\varphi_{\mathrm{P}_{0}}\right) \times\left(1-\psi_{\mathrm{o}}\right)\right)$, refers to the energy that is dissipated or lost from photosynthetic electron 
Table 1. The O-J-I-P-test parameters formulae and definitions. See Strasser et al. (2004) for further details.

\begin{tabular}{|c|c|c|}
\hline Parameters & O-J-I-P test formulae & Definitions \\
\hline \multicolumn{3}{|c|}{ Extracted fluorescence parameters } \\
\hline $\mathrm{F}_{\mathrm{O}}$ & & Initial fluorescence \\
\hline $\mathrm{O}\left(\mathrm{F}_{50 \text { us }}\right)$ & & Fluorescence intensity at $50 \mu \mathrm{s}$ \\
\hline $\mathrm{J}\left(\mathrm{F}_{2 \mathrm{~ms}}\right)$ & & Fluorescence intensity at $2 \mathrm{~ms}$ \\
\hline $\mathrm{I}\left(\mathrm{F}_{30 \mathrm{~ms}}\right)$ & & Fluorescence intensity at $30 \mathrm{~ms}$ \\
\hline $\mathrm{P}$ or $\mathrm{F}_{\mathrm{m}}$ & & Maximum fluorescence \\
\hline $\mathrm{F}_{100 \text { us }}$ & & Fluorescence intensity at $100 \mu \mathrm{s}$ \\
\hline $\mathrm{F}_{300 \mu \mathrm{s}}$ & & Fluorescence intensity at $300 \mu \mathrm{s}$ \\
\hline $\mathrm{t}_{\mathrm{Fm}}$ & & Time to reach $\mathrm{F}_{\mathrm{m}}$ (ms) \\
\hline \multicolumn{3}{|c|}{ Calculated parameters } \\
\hline $\mathrm{F}_{\mathrm{v}}$ & $=\left(\mathrm{F}_{\mathrm{m}}-\mathrm{F}_{\mathrm{O}}\right)$ & Variable fluorescence \\
\hline $\mathrm{V}_{\mathrm{J}}$ & $=\left[\left(\mathrm{F}_{2 \mathrm{~ms}}-\mathrm{F}_{\mathrm{O}}\right) /\left(\mathrm{F}_{\mathrm{m}}-\mathrm{F}_{\mathrm{O}}\right)\right]$ & Relative variable fluorescence at J-step \\
\hline $\mathrm{M}_{\mathrm{O}}$ & $=\left[4 .\left(\mathrm{F}_{300 \mu \mathrm{s}}-\mathrm{F}_{50 \mu \mathrm{s}}\right) /\left(\mathrm{F}_{\mathrm{m}}-\mathrm{F}_{50 \mu \mathrm{s}}\right)\right.$ & Net rate of PSII closure \\
\hline Área & & Area between the fluorescence curve and $\mathrm{F}_{\mathrm{m}}$ \\
\hline $\mathrm{S}_{\mathrm{M}}$ & $=\left(\operatorname{area} / \mathrm{F}_{\mathrm{v}}\right)$ & Normalised area \\
\hline \multicolumn{3}{|c|}{ Specific fluxes (RC) } \\
\hline $\mathrm{ABS} / \mathrm{RC}$ & $=\left[\left(\mathrm{TR}_{\mathrm{O}} / \mathrm{RC}\right) /\left(\mathrm{TR}_{\mathrm{O}} / \mathrm{ABS}\right)\right]$ & Effective antenna size of an active RC \\
\hline $\mathrm{TR}_{\mathrm{o}} / \mathrm{RC}$ & $=\left(\mathrm{M}_{\mathrm{O}} / \mathrm{V}_{\mathrm{J}}\right)$ & Maximal trapping rate per RC \\
\hline $\mathrm{DI}_{\mathrm{O}} / \mathrm{RC}$ & $=\left[(\mathrm{ABS} / \mathrm{RC})-\left(\mathrm{TR}_{\mathrm{O}} / \mathrm{RC}\right)\right]$ & Dissipation of an active RC \\
\hline $\mathrm{ET}_{\mathrm{O}} / \mathrm{RC}$ & $=\left[\left(\mathrm{TR}_{\mathrm{O}} / \mathrm{RC}\right)\left(\mathrm{ET}_{\mathrm{O}} / \mathrm{TR}_{\mathrm{O}}\right)\right]$ & Electron transport of an active RC \\
\hline \multicolumn{3}{|c|}{ Phenomenological fluxes (CS) } \\
\hline $\mathrm{ABS} / \mathrm{CS}$ & Approximately proportional to $\mathrm{F}_{\mathrm{O}}$ & Number of photons absorbed per CS \\
\hline $\mathrm{TR}_{\mathrm{o}} / \mathrm{CS}$ & $=(\mathrm{ABS} / \mathrm{CS})\left(\mathrm{TR}_{\mathrm{O}} / \mathrm{ABS}\right)$ & Energy flux for trapping per CS \\
\hline $\mathrm{DI}_{\mathrm{o}} / \mathrm{CS}$ & $=(\mathrm{ABS} / \mathrm{CS})-\left(\mathrm{TR}_{\mathrm{O}} / \mathrm{CS}\right)$ & Energy dissipation per CS \\
\hline $\mathrm{ET}_{\mathrm{o}} / \mathrm{CS}$ & $=\left(\mathrm{ET}_{\mathrm{o}} / \mathrm{RC}\right)(\mathrm{RC} / \mathrm{CS})$ & Electron transport per CS \\
\hline $\mathrm{RC} / \mathrm{CS}$ & $=(\mathrm{ABS} / \mathrm{CS})(\mathrm{RC} / \mathrm{ABS})$ & Density of reaction centres per CS \\
\hline \multicolumn{3}{|c|}{ Yields (or flux ratios) } \\
\hline$\varphi_{\mathrm{Po}}=\left(\mathrm{TR}_{\mathrm{O}} / \mathrm{ABS}\right)$ & $=\mathrm{F}_{\mathrm{v}} / \mathrm{F}_{\mathrm{m}}=1-\left(\mathrm{F}_{\mathrm{o}} / \mathrm{F}_{\mathrm{m}}\right)$ & $\begin{array}{l}\text { Maximum quantum yield of primary } \\
\text { photochemistry }\end{array}$ \\
\hline$\varphi_{\mathrm{Do}}=\left(\mathrm{DI}_{\mathrm{o}} / \mathrm{ABS}\right)$ & $=\mathrm{DI}_{\mathrm{O}} / \mathrm{ABS}=1-\varphi_{\mathrm{Po}}=\left(\mathrm{F}_{\mathrm{O}} / \mathrm{F}_{\mathrm{m}}\right)$ & $\begin{array}{l}\text { Maximum quantum yield of non- } \\
\text { photochemical de-excitation }\end{array}$ \\
\hline$\psi_{\mathrm{o}}=\left(\mathrm{ET}_{\mathrm{o}} / \mathrm{TR}_{\mathrm{O}}\right)$ & $=1-\mathrm{V}_{\mathrm{J}}$ & $\begin{array}{l}\text { Probability that a trapped exciton moves an } \\
\text { electron further than } \mathrm{Q}_{\mathrm{A}}^{-}\end{array}$ \\
\hline$\varphi_{\mathrm{Eo}}=\left(\mathrm{ET}_{\mathrm{O}} / \mathrm{ABS}\right)$ & $=\left(1-\mathrm{F}_{\mathrm{O}} / \mathrm{F}_{\mathrm{m}}\right)\left(1-\mathrm{V}_{\mathrm{J}}\right)$ & $\begin{array}{l}\text { Probability that an absorbed photon moves } \\
\text { an electron further than } \mathrm{Q}_{\mathrm{A}}^{-}\end{array}$ \\
\hline \multicolumn{3}{|l|}{ Performance index } \\
\hline $\mathrm{PI}_{\mathrm{ABS}}$ & $=(\mathrm{RC} / \mathrm{CS})\left[\varphi_{\mathrm{P}_{0}} /\left(1-\varphi_{\mathrm{P}_{0}}\right)\right]\left[\psi_{0} /\left(1-\psi_{0}\right)\right]$ & Performance index \\
\hline
\end{tabular}

transport, in which $\mathrm{Chl}_{\text {tot }}$ is the total Chl $a$ concentration, and $\mathrm{Chl}_{\text {tot }}=\mathrm{Chl}_{\text {antenna }}+\mathrm{Chl}_{\mathrm{RC}}$ (Strasser et al., 1999).

The combination of both structure-function indexes leads to the expression performance index (PI) and when based on absorption of antenna Chls of PSII $\left(\mathrm{PI}_{\mathrm{ABS}}\right)$ can be represented as:

$\mathrm{PI}_{\mathrm{ABS}}=\mathrm{SFI}_{\mathrm{po}(\mathrm{ABS})} / \mathrm{SFI}_{\mathrm{No}(\mathrm{ABS})}=\left\{\left(\mathrm{Chl}_{\mathrm{RC}} / \mathrm{Chl}_{\mathrm{tot}}\right) /\left[1-\left(\mathrm{Chl}_{\mathrm{RC}}{ }^{\prime}\right.\right.\right.$ $\left.\left.\left.\mathrm{Chl}_{\text {tot }}\right)\right]\right\} \times\left[\varphi_{\mathrm{Po}_{0}} /\left(1-\varphi_{\mathrm{P}_{0}}\right)\right] \times\left[\psi_{\mathrm{o}} /\left(1-\psi_{\mathrm{o}}\right)\right]=\left(\mathrm{Chl}_{\mathrm{RC}} / \mathrm{Chl}_{\text {antenna }}\right) \mathrm{x}$
$\left[\varphi_{\mathrm{P}_{0}} /\left(1-\varphi_{\mathrm{P}_{0}}\right)\right] \times\left[\psi_{0} /\left(1-\psi_{0}\right)\right]$,

or, in terms of the expression used in the O-J-I-P-test (Srivastava et al., 1999):

$\mathrm{PI}_{\mathrm{ABS}}=(\mathrm{RC} / \mathrm{ABS}) \times\left[\varphi_{\mathrm{Po}_{0}} /\left(1-\varphi_{\mathrm{Po}}\right)\right] \times\left[\psi_{\mathrm{o}} /\left(1-\psi_{\mathrm{o}}\right)\right]$.

Experimental design and statistical analysis: The experiment was arranged in a completely randomized design in a 2x2 factorial scheme with two species (co- 
paiba and mahogany) and two irradiance environments (shade and full sunlight). For each treatment 10 replicates (seedlings) were used. The results were submitted to variance analysis and the means were compared by the Tukey test at $5 \%$ probability. The statistical analyses were conducted using the software SYSTAT (version 8.0).

\section{RESULTS}

Analysis of Chl a fluorescence transients: The leaves of the copaiba and mahogany plants under shade exhibited typical polyphasic Chl $a$ fluorescence O-J-I-P transients, rising from an initial fluorescence level $\left(\mathrm{F}_{\mathrm{O}}\right)$ to the maximum fluorescence level $\left(\mathrm{F}_{\mathrm{m}}\right)$ (Figure 1A-B). Thus, Chl $a$ fluorescence transients rose sharply from $\mathrm{O}$ to $\mathrm{P}$ steps under shade compared to sunlight. Furthermore, leaves under full sunlight failed to show typical Chl $a$ fluorescence O-J-I-P transients. The times $\left(\mathrm{t}_{\mathrm{Fm}}\right)$ to reach maximum fluorescence in both species under shade were higher than under sunlight (Table 2). The area beneath the fluorescence curve between $F_{0}$ and $F_{m}$ were lower in sunlight than in shade, suggesting a decrease in the electron pool size of PSII, including $Q_{A}, Q_{B}$ and PQ (Figure 1A-B, Table 2) (Joliot and Joliot, 2002).

Under shade, copaiba presented a higher increase in fluorescence intensity at $2 \mathrm{~ms}$ ( $\mathrm{J}$ phase) than mahogany, suggesting an accumulation of the fraction of reduced $\mathrm{Q}_{\mathrm{A}}{ }^{-}$pool (Figure 1C-D). In addition, mahogany under shade presented higher values than copaiba for the area beneath the fluorescence curve between $F_{o}$ and $F_{m}$, suggesting that mahogany exhibited the highest electron pool size of PSII (Table 2). The resulting difference of normalized transients $\Delta \mathrm{W}_{\text {OJ }}$ between sunlight and shade allowed the visualization of the K-band in copaiba (Figure 1E) and mahogany (Figure 1F). This indicates that the k-band was more pronounced after high irradiance compared to shade.

Chl a fluorescence parameters (specific and phenomenological fluxes): Examination of the specific flux (per RC) showed an increase in the functional "antenna size" i.e. (ABS/RC), as given by light absorbed per active $\mathrm{RC}$ in seedlings under high irradiance. The increases of ABS/ RC were close to 4.7 -fold and 2.3-fold in copaiba and mahogany under full sunlight compared to shade, respectively (Figure 2A). This increase in ABS/RC was due to an inactivation of active RC units per cross section (RC/CS) under high irradiance (Table 3). The trapping rate of PSII ( $\mathrm{TR}_{\mathrm{O}} / \mathrm{RC}$ ) was $42 \%$ and $47 \%$ higher in copaiba and mahogany, respectively, under full sunlight compared to shade (Figure 2B). In addition, due to the excess of energy and the decrease of RC/CS under high irradiance, an increase of 17.6-fold and 6.4-fold was observed in the effective dissipation per active $\mathrm{RC}\left(\mathrm{DI}_{\mathrm{O}} / \mathrm{RC}\right)$ in copaiba and mahogany, respectively (Figure 2C). As a result of high $\mathrm{DI}_{\mathrm{O}} / \mathrm{RC}$, the values of $\mathrm{ET}_{\mathrm{o}} / \mathrm{RC}$ were $75 \%$ and $80 \%$ in mahogany and copaiba seedlings, respectively, under full sunlight compared to shade (Figure 2D).

Between the studied species it was observed that in both irradiance environments copaiba seedlings presented the highest values of ABS/RC (135\% in sunlight against $16 \%$ in shade), $\mathrm{TR}_{\mathrm{O}} / \mathrm{RC}$ ( $8 \%$ in sunlight and $12 \%$ in shade) and $\mathrm{DI}_{\mathrm{o}} / \mathrm{RC}$ (239\% in sunlight and $38 \%$ in shade) than mahogany (Figure 2A-C). However, due to the high values of $\mathrm{DI}_{\mathrm{o}} / \mathrm{RC}$ in copaiba, the electron transport rates in active RC were $24 \%$ and $56 \%$ higher in mahogany than in copaiba under shade and sunlight, respectively (Figure 2D).

Considering the phenomenological fluxes, it was found that copaiba and mahogany presented higher values of $\mathrm{TR}_{\mathrm{O}} / \mathrm{CS}$ and $\mathrm{ET}_{\mathrm{o}} / \mathrm{CS}$ under shade than sunlight (Figure 3B, 3D). In addition, the values of $\mathrm{DI}_{\mathrm{o}} / \mathrm{CS}$ were $155 \%$ and $253 \%$ higher in mahogany and copaiba, respectively, under full sun than under shade (Figure 3C).

Copaiba seedlings showed higher values of ABS/CS (15\%), $\mathrm{TR}_{\mathrm{o}} / \mathrm{CS}(10 \%)$ and $\mathrm{DI}_{\mathrm{o}} / \mathrm{CS}(37 \%)$ than mahogany under shade (Figure 3A-C). Under high irradiance, copaiba presented the lowest value of $\mathrm{TR}_{\mathrm{O}} / \mathrm{CS}$ and the highest value of $\mathrm{DI}_{\mathrm{O}} / \mathrm{CS}$ (Figure 3B-C). For $\mathrm{ET}_{\mathrm{O}} / \mathrm{CS}$, in both irradiance environments, mahogany exhibited the highest values (Figure 3D).

Yields and performance index: The results of flux ratio (yields) demonstrated that both copaiba and mahogany presented a decrease in $\mathrm{TR}_{\mathrm{O}} / \mathrm{ABS}\left(\varphi_{\mathrm{P}_{\mathrm{O}}}\right), \mathrm{ET}_{\mathrm{O}} / \mathrm{TR}_{\mathrm{O}}\left(\psi_{\mathrm{O}}\right)$ and, consequently, in $\mathrm{ET}_{\mathrm{O}} / \mathrm{ABS}\left(\varphi_{\mathrm{EO}}\right)$ under high irradiance (Table 3). The decrease of $\varphi_{\mathrm{p}_{\mathrm{o}}}$ in mahogany (36\%) and copaíba (69\%) under high irradiance indicates a loss of maximum quantum efficiency of primary 

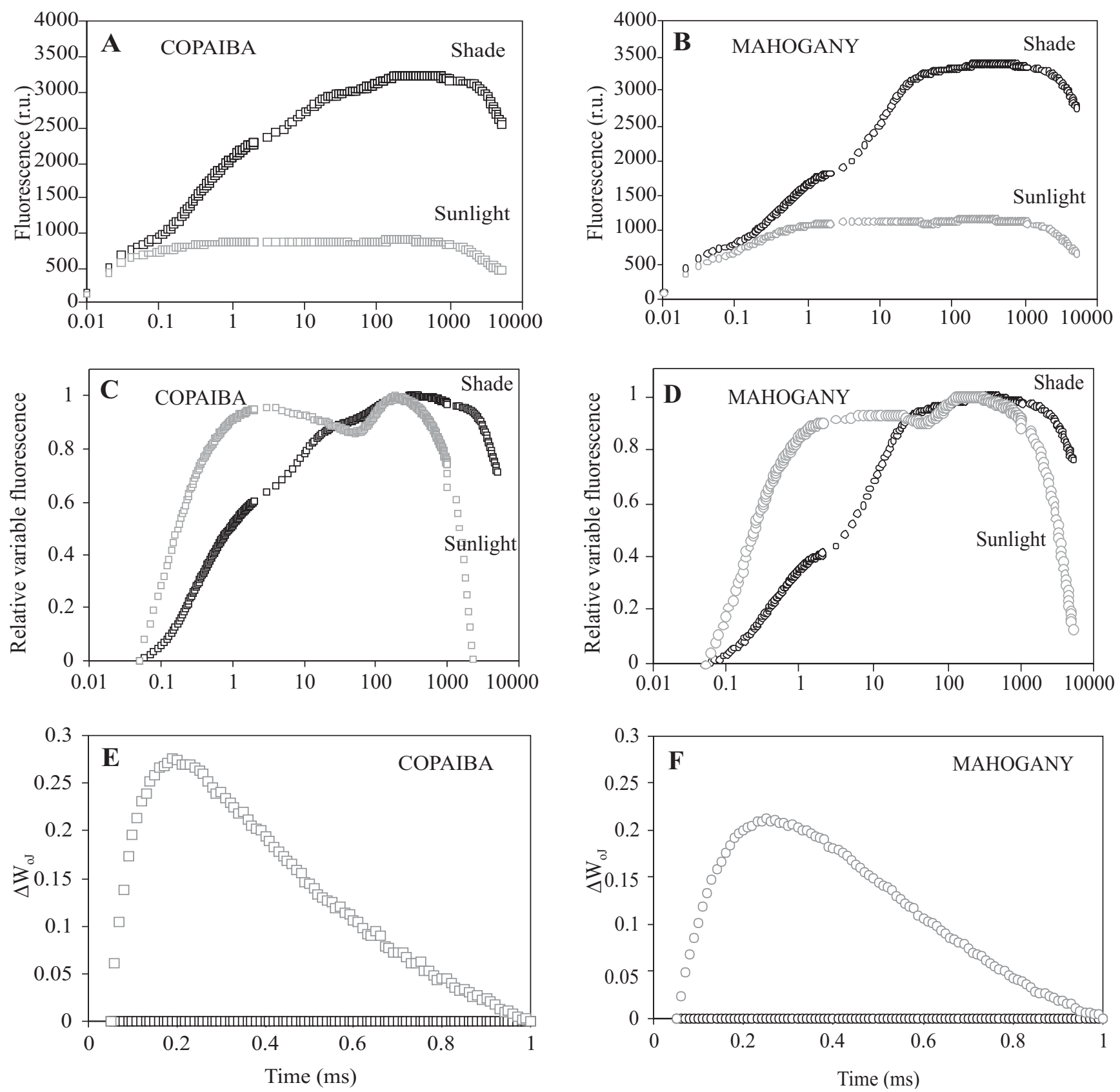

Figure 1: (A, B) - Polyphasic Chl a fluorescence transients recorded in copaiba and mahogany under shade and sunlight. Each transient represents the mean of 10 transients. (C, D) - Transients normalized between $\mathrm{O}$ and P. (E, F) Change in the shape of the $\mathrm{Chl} a$ fluorescence transient curves normalized between $\mathrm{O}$ and $\mathrm{J}\left(\mathrm{W}_{\mathrm{OJ}}\right)$ showing $\mathrm{k}-\mathrm{band} . \Delta \mathrm{W}_{\mathrm{OJ}}$ $=\left(\mathrm{W}_{\mathrm{OJ}(\text { sunlight })}-\mathrm{W}_{\mathrm{OJ}(\text { (shade) }}\right)$.

photochemistry due to photoinhibition promoted by excess energy. In addition, such excess induced an inactivation of 58 and $78 \%$ of active RC per cross section in mahogany and copaiba under sunlight, respectively, inducing an increased energy dissipation as well as lower values of $\varphi_{\mathrm{P}_{\mathrm{o}}}$ (Table 3). Further, it was verified that seedlings under sunlight presented a decrease in $\varphi_{\mathrm{EO}}$, especially for copaiba (23-fold) when compared to mahogany (nine-fold).

The performance index $\left(\mathrm{PI}_{\mathrm{ABS}}\right)$ combines three 
Table 2. Initial fluorescence $\left(\mathrm{F}_{\mathrm{O}}\right)$, fluorescence intensity at $50 \mu \mathrm{s}\left(\mathrm{O}=\mathrm{F}_{50 \mu \mathrm{s}}\right), 100 \mu \mathrm{s}\left(\mathrm{F}_{100 \mu \mathrm{s}}\right), 300 \mu \mathrm{s}\left(\mathrm{F}_{300 \mu \mathrm{s}}\right), 2 \mathrm{~ms}\left(\right.$ " $\mathrm{I}$ ” $\left.=\mathrm{F}_{2 \mathrm{~ms}}\right)$ and 30ms (“J” $=F_{30 \mathrm{~ms}}$ ), variable fluorescence $\left(\mathrm{F}_{\mathrm{v}}\right)$, maximum fluorescence $\left(\mathrm{F}_{\mathrm{m}}=\mathrm{P}\right)$, time to reach $\mathrm{F}_{\mathrm{m}}\left(\mathrm{t}_{\mathrm{Fm}}\right)$ and area beneath the fluorescence curve in copaiba and mahogany under two irradiance environments. Mean values $(n=10) \pm$ SD are shown. Mean values followed by the same capital letters for irradiance environments, and means followed by the same small letters for species are not significantly different $(P>0.05$; Tukey test).

\begin{tabular}{lccrc}
\hline \multirow{2}{*}{ Variables } & \multicolumn{2}{c}{ COPAİBA } & \multicolumn{2}{c}{ MAHOGANY } \\
\cline { 2 - 5 } $\mathrm{F}_{\mathrm{O}}$ & Sunlight & Shade & $566 \pm 102 \mathrm{Aa}$ & $593 \pm 25 \mathrm{Ab}$ \\
$\mathrm{F}_{50 \mu \mathrm{s}}(\mathrm{O})$ & $662 \pm 144 \mathrm{Aa}$ & $681 \pm 59 \mathrm{Aa}$ & $622 \pm 120 \mathrm{Aa}$ & $691 \pm 35 \mathrm{Ab}$ \\
$\mathrm{F}_{100 \mu \mathrm{s}}$ & $666 \pm 147 \mathrm{Ba}$ & $823 \pm 66 \mathrm{Aa}$ & $734 \pm 160 \mathrm{Aa}$ & $798 \pm 48 \mathrm{Ab}$ \\
$\mathrm{F}_{300 \mu s}$ & $730 \pm 178 \mathrm{Ba}$ & $971 \pm 81 \mathrm{Aa}$ & $994 \pm 257 \mathrm{Ba}$ & $1175 \pm 89 \mathrm{Ab}$ \\
$\mathrm{F}_{2 \mathrm{~ms}}(\mathrm{I})$ & $822 \pm 223 \mathrm{Ba}$ & $1494 \pm 132 \mathrm{Aa}$ & $1194 \pm 315 \mathrm{Ba}$ & $1857 \pm 124 \mathrm{Ab}$ \\
$\mathrm{F}_{30 \mathrm{~ms}}(\mathrm{~J})$ & $880 \pm 247 \mathrm{Bb}$ & $2265 \pm 193 \mathrm{Aa}$ & $1211 \pm 312 \mathrm{Ba}$ & $3214 \pm 171 \mathrm{Aa}$ \\
$\mathrm{F}_{\mathrm{v}}$ & $861 \pm 237 \mathrm{Bb}$ & $3058 \pm 200 \mathrm{Aa}$ & $697 \pm 259 \mathrm{Ba}$ & $2845 \pm 131 \mathrm{Aa}$ \\
$\mathrm{F}_{\mathrm{m}}(\mathrm{P})$ & $230 \pm 110 \mathrm{Bb}$ & $2635 \pm 171 \mathrm{Ab}$ & $1263 \pm 342 \mathrm{Ba}$ & $3438 \pm 153 \mathrm{Aa}$ \\
$\mathrm{t}_{\mathrm{Fm}}$ & $893 \pm 251 \mathrm{Bb}$ & $3317 \pm 219 \mathrm{Aa}$ & $181 \pm 85 \mathrm{Ba}$ & $339 \pm 27 \mathrm{Aa}$ \\
Area & $212 \pm 26 \mathrm{Ba}$ & $304 \pm 18 \mathrm{Ab}$ & $5000 \pm 2506 \mathrm{Ba}$ & $36489 \pm 2231 \mathrm{Aa}$ \\
\hline
\end{tabular}

independent functional steps of photosynthesis, such as the density of RCs in the chlorophyll bed, excitation energy trapping and conversion of excitation energy to electron transport, into a single multi-parametric expression (Strasser et al., 1999; Tsimilli-Michael et al., 2000). It is a function of $\psi_{0}, \varphi_{\mathrm{Po}}$, and RC/ABS (Srivastava et al., 1999). The seedlings of both species under shade exhibited much higher values of $\mathrm{PI}_{\mathrm{ABS}}$ than seedlings under full sunlight, possibly due to photoinhibition promoted by excess of light energy (Table 3). Furthermore, mahogany presented higher performance than copaiba in both irradiance environments (Table 3). The higher $\mathrm{PI}_{\mathrm{ABS}}$ in mahogany than in copaiba seedlings under shade and sunlight, (about three-fold and 14-fold higher, respectively), suggests a greater extent of photoinhibition in copaiba than in mahogany regardless of light environments.

The relationship between $\log \left(\mathrm{PI}_{\mathrm{ABS}}\right)$ rel [=Log (PI $\mathrm{ABS}_{\text {(Copaíba or Mahogany) }} / \mathrm{PI}_{\mathrm{ABS} \text { (Copaíba or Mahogany average) }}$ and the relative yield of electron transport $\left(\mathrm{ET}_{\mathrm{o}} / \mathrm{ABS}\right) \mathrm{rel}\left[=\left(\mathrm{ET}_{\mathrm{o}} /\right.\right.$ $\mathrm{ABS}_{\text {(Copaíba or Mahogany) }} / \mathrm{ET}_{\mathrm{o}} / \mathrm{ABS}$ (Copaíba or Mahogany average) $]$ in Figure 4 shows that shaded seedlings exhibited better capacity to use irradiance than seedlings under full sunlight. As expected from the above data, mahogany presented higher capacity to convert light energy into chemical energy than copaiba in both irradiance environments (Figure 5A-B).

\section{DISCUSSION}

The shape of the O-J-I-P transients is very sensitive to different light conditions. Under high irradiance the shape of the O-J-I-P transient changed in copaiba and mahogany with a severe decrease in $\mathrm{F}_{\mathrm{m}}$, resulting in lowered $\mathrm{F}_{\mathrm{v}}$ (Figure 1.A-B, Table 2). The fast rise from $\mathrm{O}$ to $\mathrm{J}$ is the photochemical phase and $\mathrm{J}$ to $\mathrm{P}$ is the thermal phase (Strasser et al., 1995; Lazar, 2003). The rise in transients from $\mathrm{O}$ to $\mathrm{J}$ and from $\mathrm{J}$ to $\mathrm{P}$ are due to the reduction of $\mathrm{Q}_{\mathrm{A}}$ to $\mathrm{Q}_{\mathrm{A}}{ }^{-}$and the reduction of the $\mathrm{PQ}$ pool (Strasser and Govindjee, 1992). Thus the high irradiance severely affected both donor and acceptor sides of PSII due the disconnected oxygen-evolution complex with impairment of the electron transport chain (Figure 1.E-F). Comparing both species, stronger photoinhibition induced by excess of light energy, promoting more damage at both sides of PSII, is to be expected for copaiba than in mahogany.

The time to reach the complete reduction of PSII acceptor $\mathrm{Q}_{\mathrm{A}}$ was higher in shade than in sunlight. The shorter time under high irradiance is caused by the faster rate of $Q_{A}$ reduction due to high light availability in the environment.

Since $\mathrm{F}_{\mathrm{O}}$ remained unchanged regardless of species and treatments (Table 2), a regulatory or protective mechanism under high irradiance is to be expected (Björkman and Demmig Adams, 1987; Osmond et al., 1993). In addition, the decline in both $F_{m}$ and $F_{v} / F_{m}$ 

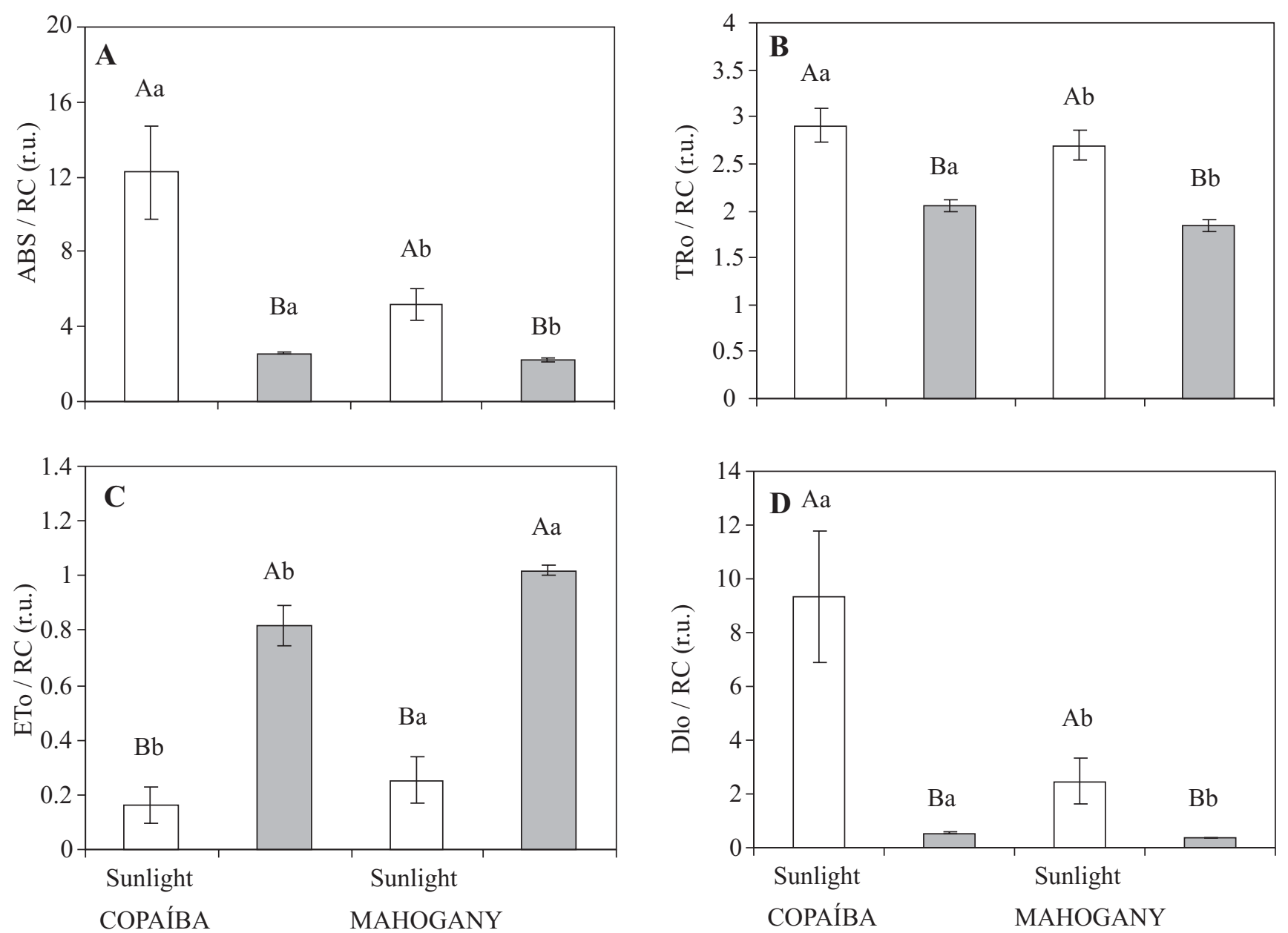

Figure 2. Specific fluxes expressed per reaction center (RC) in copaiba and mahogany under sunlight and shade environments. (A) - Flux of photons absorbed by chlorophyll molecules per active RC (ABS/RC); (B) - Energy flux for trapping that is conserved in chemical components per active $\mathrm{RC}\left(\mathrm{TR}_{\mathrm{O}} / \mathrm{RC}\right)$; $(\mathbf{C})$ - Flux of energy that enters into the electron transport chain further than $\mathrm{Q}_{\mathrm{A}}$ per active $\mathrm{RC}\left(\mathrm{ET}_{\mathrm{O}} / \mathrm{RC}\right)$; (D) - Flux of energy that is dissipated in the form of heat and fluorescence, or transferred to other systems per active RC (DI $/ \mathrm{RC}$ ). Statistics as in Table 2.

Table 3. Density of active reaction centers per cross section (RC/CS), maximum efficiency of PSII $\left(\varphi_{\mathrm{P}_{0}}=\mathrm{TR}_{\mathrm{O}} / \mathrm{ABS}\right)$, maximum efficiency of non-photochemical de-excitation $\left(\varphi_{\mathrm{Do}_{0}}=\mathrm{DI}_{\mathrm{O}} / \mathrm{ABS}\right)$, probability that a trapped exciton $\left(\psi_{\mathrm{o}}=\mathrm{ET}_{\mathrm{O}} /\right.$ $\left.\mathrm{TR}_{\mathrm{O}}\right)$ or that an absorbed photon $\left(\varphi_{\mathrm{Eo}}=\mathrm{ET}_{\mathrm{O}} / \mathrm{ABS}\right)$ can move an electron further from $\mathrm{Q}_{\mathrm{A}}$, and performance index $\left(\mathrm{PI}_{\mathrm{ABS}}\right)$ in copaiba and mahogany under two irradiance environments. Statistics as in Table 2.

\begin{tabular}{|c|c|c|c|c|}
\hline \multirow[b]{2}{*}{ Variables } & \multicolumn{2}{|c|}{ COPAÍBA } & \multicolumn{2}{|c|}{ MAHOGANY } \\
\hline & Sunlight & Shade & Sunlight & Shade \\
\hline $\mathrm{RC} / \mathrm{CS}$ & $58 \pm 23 \mathrm{Bb}$ & $264 \pm 21 \mathrm{Aa}$ & $113 \pm 29 \mathrm{Ba}$ & $265 \pm 4 \mathrm{Aa}$ \\
\hline $\mathrm{TR}_{\mathrm{O}} / \mathrm{ABS}\left(\varphi_{\mathrm{Po}_{\mathrm{o}}}\right)$ & $0.25 \pm 0.05 \mathrm{Bb}$ & $0.80 \pm 0.01 \mathrm{Ab}$ & $0.53 \pm 0.08 \mathrm{Ba}$ & $0.83 \pm 0.003 \mathrm{Aa}$ \\
\hline $\mathrm{DI}_{\mathrm{O}} / \mathrm{ABS}\left(\varphi_{\mathrm{Do}_{0}}\right)$ & $0.75 \pm 0.05 \mathrm{Aa}$ & $0.20 \pm 0.01 \mathrm{Ba}$ & $0.47 \pm 0.08 \mathrm{Ab}$ & $0.17 \pm 0.003 \mathrm{Bb}$ \\
\hline $\mathrm{ET}_{\mathrm{O}} / \mathrm{TR}_{\mathrm{O}}\left(\psi_{0}\right)$ & $0.057 \pm 0.024 \mathrm{Bb}$ & $0.399 \pm 0.041 \mathrm{Ab}$ & $0.095 \pm 0.033 \mathrm{Ba}$ & $0.556 \pm 0.018 \mathrm{Aa}$ \\
\hline $\mathrm{ET}_{\mathrm{O}} / \mathrm{ABS}\left(\varphi_{\mathrm{Eo}}\right)$ & $0.014 \pm 0.006 \mathrm{Bb}$ & $0.317 \pm 0.030 \mathrm{Ab}$ & $0.052 \pm 0.022 \mathrm{Ba}$ & $0.460 \pm 0.015 \mathrm{Aa}$ \\
\hline $\mathrm{PI}_{\mathrm{ABS}}$ & $0.002 \pm 0.001 \mathrm{Bb}$ & $1.013 \pm 0.186 \mathrm{Ab}$ & $0.028 \pm 0.019 \mathrm{Ba}$ & $2.725 \pm 0.286 \mathrm{Aa}$ \\
\hline
\end{tabular}



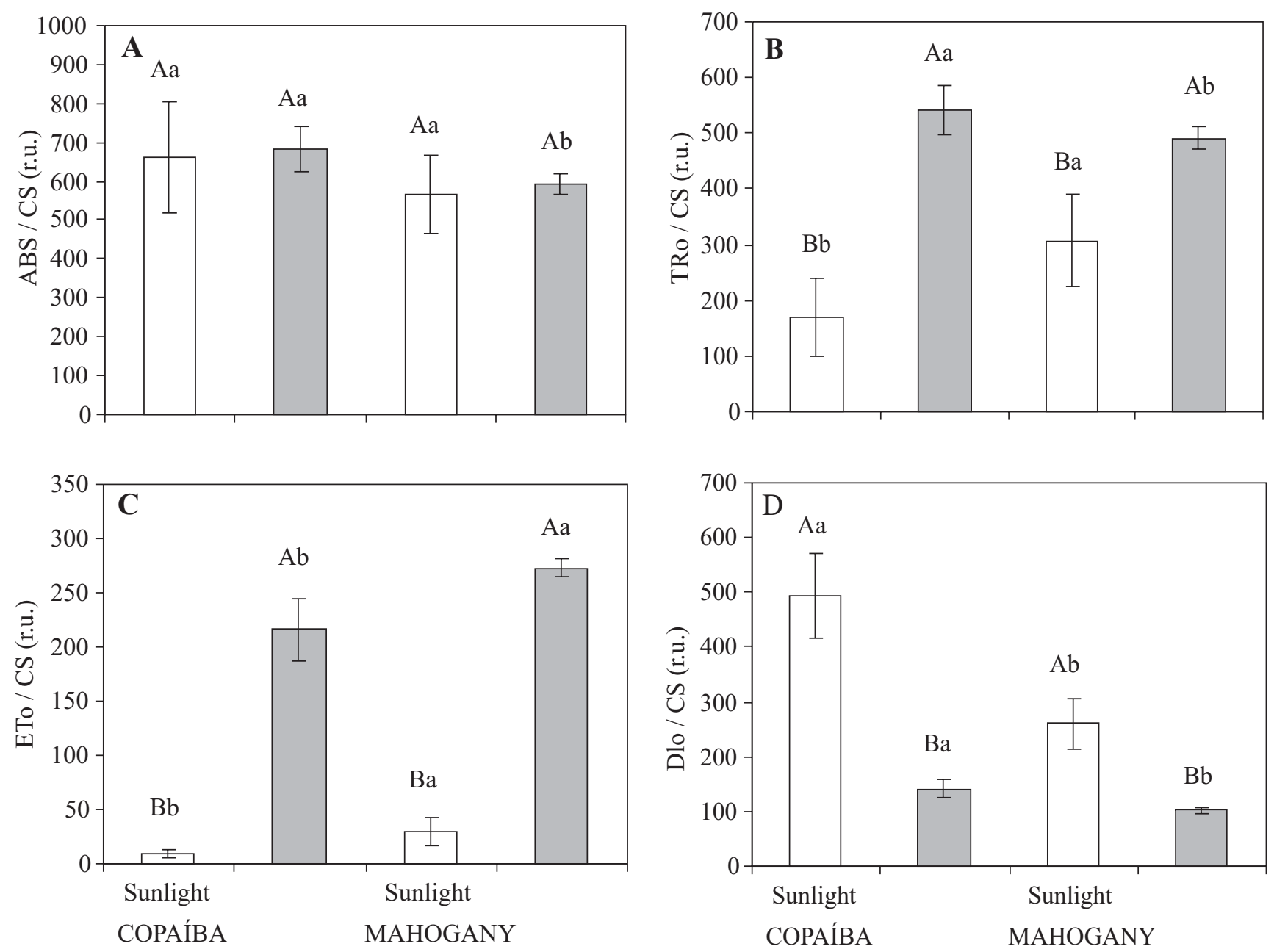

Figure 3. Phenomenological fluxes expressed per cross section of leaf tissue (CS) in copaiba and mahogany under sunlight and shade environments. (A) - Flux of photons absorbed by chlorophyll molecules per CS (ABS/CS); (B) Energy flux for trapping that is conserved in chemical components per CS (TR $/ C S)$; (C) - Flux of energy that enters into the electron transport chain further than $\mathrm{Q}_{\mathrm{A}}$ per CS (ET $\left./ \mathrm{CS}\right)$; (D) - Flux of energy that is dissipated in the form of heat and fluorescence, or transferred to other systems per CS (DI/CS). Statistics as in Table 2.

indicates an adaptation to a physiological state which requires, under high-irradiance conditions, a much lower quantum yield of PSII to sufficiently reduce the primary acceptor $\mathrm{Q}_{\mathrm{a}}^{-}$.

The high irradiance induced a severe decrease in the area above the fluorescence between $\mathrm{F}_{\mathrm{O}}$ and $\mathrm{F}_{\mathrm{m}}$ in seedlings under sunlight, indicating a reduction in the pool size of PSII (Strasser et al., 1995; Joliot and Joliot, 2002).

The $\varphi_{\mathrm{Po}_{0}}\left(\mathrm{~F}_{\mathrm{v}} / \mathrm{F}_{\mathrm{m}}=\mathrm{TR} \mathrm{R}_{\mathrm{O}} / \mathrm{ABS}\right)$ is a parameter that expresses the maximum efficiency of PSII which is controlled by the primary photochemistry of PSII (charge separation, recombination and stabilization), non- radiative loss of excited states in light-harvesting antennae and by excited states quenched by oxidized PQ molecules from the PQ pool (Lazar, 2003). The low values of $\varphi_{\mathrm{P}_{\mathrm{o}}}$ in seedlings under high irradiance could have resulted from the inactivity of $\mathrm{RC}$, which might favor higher energy dissipation as heat and fluorescence, as deduced from the high values for $\varphi_{\text {Do }}$. This might be associated with increased heat sinks (heat-sink centers or silent centers). These heat sinks may absorb light in a similar manner to active RC, but are unable to store the excitation energy as redox energy, dissipating their total energy as heat (Hermans et al., 2003). In addition, due to excess of irradiance, transfer of energy to other systems 

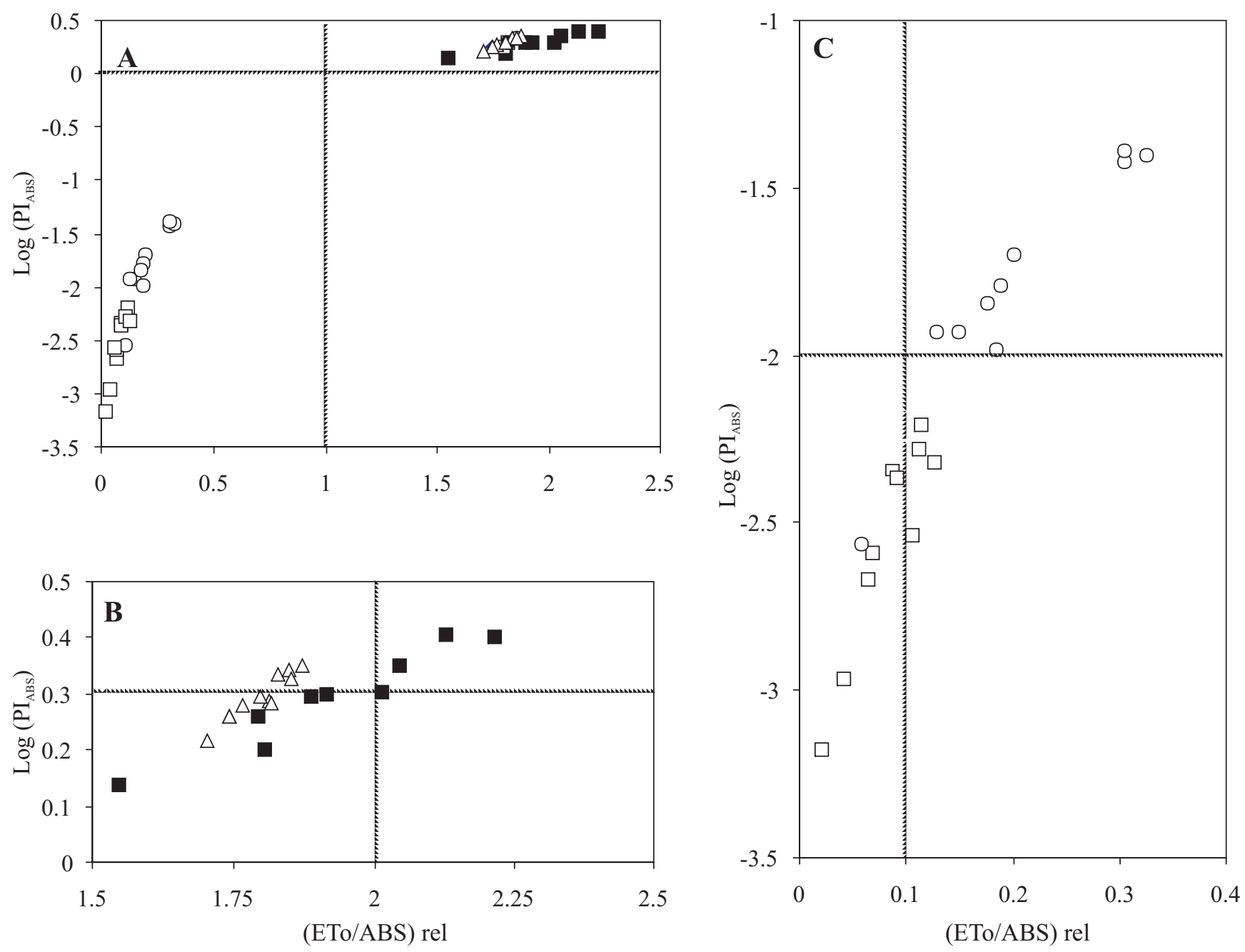

Figure 4. (A) - Relationship between the log function of the relative Performance Index $\left(\log \left(\mathrm{PI}_{\mathrm{ABS}}\right) r e l\right)\left[=\mathrm{Log}_{(\mathrm{PI}}{ }_{\mathrm{ABS}(\mathrm{copaiba}}\right.$ or Mahogany) $\left./ \mathrm{PI}_{\mathrm{ABS} \text { (copaiba or mahogany average) }}\right]$ and the relative yield of electron transport (ET/ABS)rel $\left[=\left(\mathrm{ET}_{\mathrm{o}} / \mathrm{ABS}_{\text {(copaiba or mahogany) }}\right.\right.$
/ ET /ABS squares represent copaiba under shade and sunlight, respectively. The empty triangles and empty circles represent mahogany under sunlight and shade, respectively.

such as energy-dependent formation of reactive oxygen species could also took place (Strasser et al., 2000).

Analyzing $\psi_{0}$, the lowest values of $\varphi_{\mathrm{P}_{0}}$ were found in seedlings under high irradiance. The values of $\psi_{0}$ decreased to a remarkably greater extent in both mahogany and copaiba under sunlight than in shade. This result reflects a reduction in the pool of plastoquinone in an oxidized state (PQ) and reoxidation inhibition of $\mathrm{Q}_{\mathrm{A}}{ }^{-}$, and demonstrates that besides the loss of energy to $Q_{A}$ the loss of excitation energy further from $\mathrm{Q}_{\mathrm{A}}$ was significant (Force et al., 2003). Results of $\varphi_{\mathrm{Po}}, \psi_{0}$ and $\varphi_{\text {Eo }}$ allow us to deduce that mahogany may use light energy more efficiently than copaiba under both shade and full sunlight conditions (Table 3).

The performance index $\left(\mathrm{PI}_{\mathrm{ABS}}\right)$ is a consistent parameter to evaluate the plant performance in light energy absorption, excitation energy trapping and conversion of excitation energy to electron transport by photosynthesis under stress conditions of irradiance, drought, heat, dark chilling, ozone and salt (Clark et al., 2000; Misra et al., 2001; De Ronde et al., 2004; Gonçalves and Santos Junior, 2005b; Strauss et al., 2006). As observed in this study, $\mathrm{PI}_{\mathrm{ABS}}$ was much lower in full-sungrown seedlings. Among the factors that have likely 

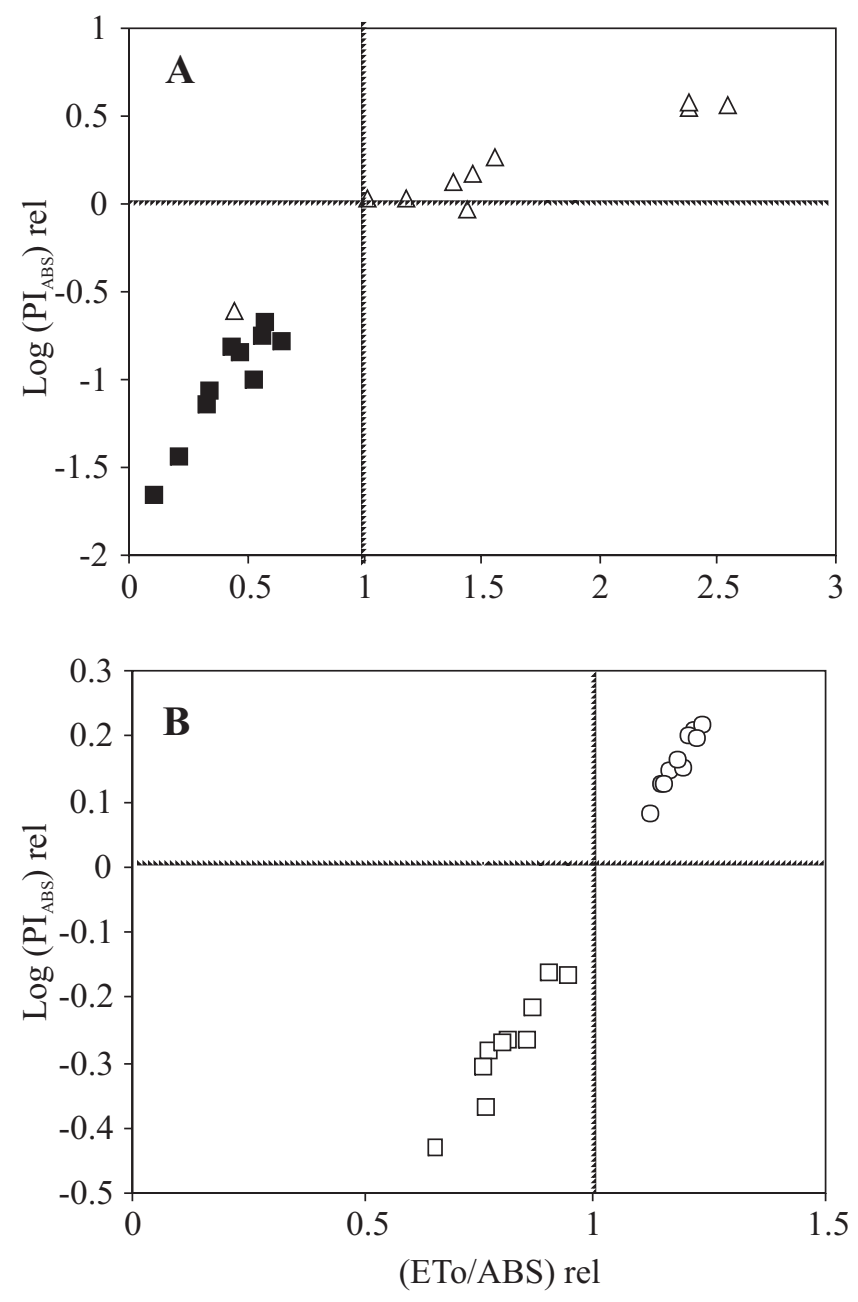

Figure 5. (A) - Relationship between the log function of the relative Performance Index $\left(\mathrm{Log}\left(\mathrm{PI}_{\mathrm{ABS}}\right)\right.$ rel) $[=\mathrm{Log}$ $\left(\mathrm{PI}_{\mathrm{ABS} \text { (sunlight) }} / \mathrm{PI}_{\mathrm{ABS}(\text { sunlight average) }}\right.$ and the relative yield of electron transport (ET/ABS)rel $\left[=\left(\mathrm{ET}_{0} / \mathrm{ABS}_{\text {(sunlight) }} / \mathrm{ET}_{\mathrm{o}} /\right.\right.$ $\left.\mathrm{ABS}_{\text {(sunlight average) }}\right]$. (B) - Relationship between the $\log$ function of the relative Performance Index $\left(\log \left(\mathrm{PI}_{\mathrm{ABS}}\right) \mathrm{rel}\right)$ $\left[=\log \left(\mathrm{PI}_{\mathrm{ABS} \text { (shade) }} / \mathrm{PI}_{\mathrm{ABS} \text { (shade average) }}\right.\right.$ and the relative yield of electron transport (ET/ABS)rel $\left[=\left(\mathrm{ET}_{0} / \mathrm{ABS}_{\text {(shade) }} / \mathrm{ET}_{\mathrm{o}} /\right.\right.$

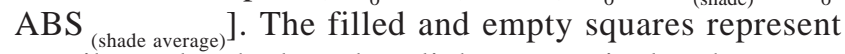
copaiba under shade and sunlight, respectively. The empty triangles and empty circles represent mahogany under sunlight and shade, respectively.

contributed to such low values are: inactivation of a high number of active RC per leaf area, excess of light energy, low maximum quantum efficiency of PSII, and low electron transport rate beyond $\mathrm{Q}_{\mathrm{A}}{ }^{-}$. In addition, low values of RC/CS and $\varphi_{\mathrm{P}_{0}}$ suggest that a high proportion of the energy absorbed was dissipated as heat and fluorescence.
The $\mathrm{PI}_{\mathrm{ABS}}$ expresses both a function of the fluorescence extreme $\mathrm{F}_{\mathrm{o}}$ and $\mathrm{F}_{\mathrm{m}}$, as well as the intermediate J-step and the slope at the origin of the fluorescence rise, whereas $\varphi_{\mathrm{P}_{0}}$ expresses a function of only $\mathrm{F}_{\mathrm{O}}$ and $\mathrm{F}_{\mathrm{m}}$ independently of how the trajectory of the fluorescence intensity reaches its maximal value (Strauss et al., 2006). Furthermore, $\mathrm{PI}_{\mathrm{ABs}}$ allows broader analysis of photosynthetic performance such as the relationship between photon absorption efficiency and capture of excited energy in PSII, as well as analysis of density of active RC and the probability that excited energy moves an electron further than $\mathrm{Q}_{\mathrm{A}}^{-}$(Gonçalves and Santos Junior, 2005a). Therefore, $\mathrm{PI}_{\mathrm{ABS}}$ is a better parameter to evaluate responses of PSII to stressful conditions than $\varphi_{\mathrm{Po}}$ alone.

The correlation between log $\left(\mathrm{PI}_{\mathrm{ABS}}\right)$ rel and $\left(\mathrm{ET}_{\mathrm{O}} /\right.$ ABS)rel can be considered a typical property of a plant's capacity to transform light energy into chemical energy, which is directed into metabolic reactions in the biochemical process of photosynthesis (Hermans et al., 2003). The low values of ( $\left.\mathrm{ET}_{\mathrm{O}} / \mathrm{ABS}\right) \mathrm{rel}$ and $\log \left(\mathrm{PI}_{\mathrm{ABS}}\right)$ rel in copaiba and mahogany under the stress condition, caused by high free energy availability in the system, suggest that adaptation to full sunlight of these species at the seedling stage is thermodynamically unfavorable due to the difficulty of using the excess energy in the photosynthetic process. On the other hand, under low irradiance, the thermodynamically optimal state is more easily achieved due to minimal entropy production, as a result of low free energy in the system.

The similar performance of mahogany seedlings under both sun and shade when compared to the contrasting performance of copaiba seedlings also under both sun and shade conditions (Figure 4A; see details in Figure $4 \mathrm{~B}-\mathrm{C}$ ), and the superior performance of mahogany in both light environments (Figure 5A-B), suggest that this species is more plastic than copaiba for using the available energy at seedling stages.

\section{CONCLUSIONS}

We conclude that the investigation of the shape of OJ-I-P transients and the parameters obtained using Chl $a$ fluorescence such as the performance index were effective to evaluate the efficiency in capture and use of low and high light under shade and sunlight, respectively, in copaiba and mahogany seedlings. 
Copaiba and mahogany were not very efficient in their use of excess energy under high irradiance, suffering from photoinhibition. In contrast, seedlings use light energy more efficiently under low irradiance due to minimal entropy production. Mahogany presented higher plasticity for using the available energy than copaiba in both irradiance treatments. This suggests that mahogany has a greater capacity to become established under contrasting light environments than does copaiba in the juvenile phase. Finally, these indexes could also possibly be of great value as screening tools for high-irradiance tolerance of tree species in highly degraded areas.

Acknowledgements: The authors are thankful to the National Institute of Amazonian Research and members of Laboratory of Plant Physiology and Biochemistry (MCT-INPA) for their technical assistance during the analyses. JFC Gonçalves acknowledges a fellowship granted by the National Council for Scientific and Technological Development (CNPq, Brazil).

\section{REFERENCES}

Baker NR, Rosenqvist E (2004) Application of chlorophyll fluorescence can improve crop production strategies: an examination of future possibilities. J. Exp. Bot. 55:1607-162121.

Bjorkman O, Demmig-Adams B (1987) Photon yield of O2 evolution and chlorophyll fluorescence characteristics at $77 \mathrm{k}$ among vascular plants of diverse origins. Planta 170:489-504.

Clark AJ, Landolt W, Bucher JB, Strasser RJ (2000) Beech (Fagus sylvatica) response to ozone exposure assessed with a chlorophyll $a$ fluorescence performance index. Environ. Pollut. 109:501-507.

De Ronde JA, Cress WA, Kruger GHJ, Strasser RJ, Van Staden J (2004) Photosynthetic response of transgenic soybean plants, containing an Arabidopsis P5CR gene, during heat and drought stress. J. Plant Physiol. 161:1211-1224.

Dekker JP, Van Grondelle R (2000) Primary charge separation in photosystem II. Photosynth. Res. 63:195208.

Force L, Critchley C, Rensen JJS (2003) New fluorescence parameters for monitoring photosynthesis in plants. Photosynth. Res. 78:17-33.
Gonçalves JFC, Marenco RA, Vieira G (2001) Concentration of photosynthetic pigments and chlorophyll fluorescence of mahogany and tonka bean under two light environments. Braz. J. Plant Physiol. 13:149-157.

Gonçalves JFC, Barreto DCS, Santos Junior UM, Fernandes AV, Sampaio PTB, Buckeridge MS (2005) Growth, photosynthesis and stress indicators in young rosewood plants (Aniba rosaeodora Ducke) under different light intensities. Braz. J. Plant Physiol. 17:325-334.

Gonçalves JFC, Santos Junior UM (2005a) Assimilação de carbono e indicadores de estresse da Amazônia. In: Nogueira RJMC, Araújo EL, Willadino LG, Cavalcante UMT (eds), Estresses Ambientais: Danos e Benefícios em Plantas, pp.165-181. UFRPE, Imprensa Universitária, Recife.

Gonçalves JFC, Santos Junior UM (2005b) Utilization of the chlorophyll $a$ fluorescence technique as a tool for selecting tolerant species to environments of high irradiance. Braz. J. Plant Physiol. 17:307-313.

Hankamer B, Barber J, Boekema EJ (1997) Structure and membrane organization of photosystem II from green plants. Annu. Rev. Plant Physiol. Plant Mol. Biol. 48:641-672.

Hermans C, Smeyers M, Rodriguez RM, Eyletters M, Strasser RJ, Delhaye JP (2003) Quality assessment of urban trees: A comparative study of physiological characterization, airborne imaging and on site fluorescence monitoring by the O-J-I-P-test. J. Plant Physiol. 160:81-90.

Joliot P, Joliot A (2002). Cyclic electron transport in plant leaf. Proc. Natl. Acad. Sci. USA 99:10209-10214.

Kruger GHJ, Tsimilli-Michael M, Strasser RJ (1997) Light stress provokes plastic and elastic modifications in structure and function of photosystem II in camellia leaves. Physiol. Plant. 101:265-277.

Lazar D (2003) Chlorophyll $a$ fluorescence rise induced by high light illumination of dark-adapted plant tissue studied by means of photosystem II and considering photosystem II heterogeneity. J. Theor. Biol. 220:469503.

Maldonado-Rodríguez (2000) Biolizer: program developed in the Bioenergetics Laboratory of Geneva and available as free ware. 
Mishra AN, Srivastava A, Strasser RJ (2001) Utilization of fast chlorophyll $a$ technique in assessing the salt/ion sensitivity of mung bean and brassica seedlings. J. Plant Physiol. 158:1173-1181.

Osmond CB, Ramus J, Levavasseur G, Franklin LA, Henley WJ (1993) Fluorescence quenching during photosynthesis and photoinhibition of Ulva rotundata Blid. Planta 190:97-106.

Panda D, Rao DN, Sharma SG, Strasser RJ, Sarkar RK (2006) Submergence effects on rice genotypes during seedlings stage: Probing of submergence driven changes of photosystem II by chlorophyll $a$ fluorescence induction O-J-I-P transients. Photosynthetica 44:69-75.

Rhee KH, Morris EP, Barber J, Kuhlbrandt W (1998) Three-dimensional structure photosystem II reaction centre at 8 A resolution. Nature 396:283-86.

Santos Jr. UM, Gonçalves JFC, Feldpausch TR (2006) Growth, leaf nutrient concentration and photosynthetic nutrient use efficiency in tropical tree species planted in degraded areas in central Amazonia. For. Ecol. Manage. 226:299-309.

Sironval C, Strasser RJ, Brouers M (1981) Equivalence entre la theorie des flux et la theorie des relations entre proportions de pigments pour la description de la repartition de l'energie lumineuse absorbée par les membranes photoactives. Bull. Acad. R. Belg. 67:248-259.

Srivastava A, Strasser RJ, Govindjee (1999) Greening of peas: parallel measurements of $77 \mathrm{~K}$ emission spectra, O-J-I-P chlorophyll $a$ fluorescence transient, period four oscillation of the initial fluorescence level, delayed light emission, and P700. Photosynthetica 37:365-392.

Stirbet A, Govindjee, Strasser BJ, Strasser RJ (1998) Chlorophyll $a$ fluorescence induction in higher plants: modeling and numerical simulation. J. Theor. Biol. 193:131-151.

Strasser RJ, Govindjee (1992) The $\mathrm{F}_{\mathrm{o}}$ and O-J-I-P fluorescence rise in higher plants and algae. In: Argyroudi-Akoyunoglou JH (ed), Regulation of Chloroplast Biogenesis, pp.423-426. Plenum Press, New York.

Strasser RJ, Srivastava A, Govindjee (1995) Polyphasic chlorophyll $a$ fluorescence transient in plants and cyanobacteria. Photochem. Photobiol. 61:32-42.

Strasser RJ, Srivastava A, Tsimilli-Michael M (1999)
Screening the vitality and photosynthetic activity of plants by fluorescence transient. In: Behl RK, Punia MS, Lather BPS (eds), Crop Improvement for Food Security, pp.79-126. SSARM, Hisar.

Strasser RJ, Srivastava A, Tsimilli-Michael M (2000) The fluorescence transient as a tool to characterize and screen photosynthetic samples. In: Yunus M, Pathre U, Mohanty P (eds), Probing Photosynthesis: Mechanisms, Regulation and Adaptation, pp.445-483. Taylor \& Francis, London.

Strasser RJ, Srivastava A, Tsimilli-Michael M (2004) Analysis of chlorophyll $a$ fluorescence transient. In: Papageorgiou G, Govindjee (eds), Advances in Photosynthesis and Respiration: Chlorophyll Fluorescence a Signature of Photosynthesis, pp.321362. Kluwer Academic Publishers, Netherlands.

Strasser RJ, Tsimili-Michael M (2001) Stress in plants from daily rhythm to global changes, detected and quantified by the JIP test. Chim. Nouvelle (SRC) 75:3321-6.

Strauss AJ, Kruger GHJ, Strasser RJ, Van Heerden PDR (2006) Ranking of dark chilling tolerance in soybean genotypes probed by chlorophyll $a$ fluorescence transient O-J-I-P. Environ. Exp. Bot. 56:147-157.

Tsimilli-Michael M, Pêcheux M, Strasser RJ (1998) Vitality and stress adaptation of the symbionts of coral reef and temperate foraminifers probed in hospite by the fluorescence kinetics O-J-I-P. Arch. Sci. Genéve 51:205-240.

Tsimilli-Michael M, Eggenberg P, Biro B, Koves-Péchy K, Voros I, Strasser RJ (2000) Synergistic and antagonistic effects of arbuscular mycorrhizal fungi and Azospirillum and Rhizobium nitrogen-fixers on the photosynthetic activity of alfalfa, probed by polyphasic chlorophyll $a$ fluorescence transient O-J-IP. Appl. Soil Ecol. 15:169-182.

Veiga Jr. VF, Pinto AC (2001) The Copaifera L. genus. Quimica Nova 25:273-286.

Veiga Jr. VF, Zunino L, Calixto JB, Patitucci ML, Pinto AC (2001) Phytochemical and antioedematogenic studies of commercial Copaiba oils available in Brazil. Phytother. Res. 15:476-480.

Whitman AA, Brokaw NVL, Hagan JM (1997) Forest damage caused by selective logging of mahogany (Swietenia macrophyla) in northern Belize. For. Ecol. Manage. 92:87-96. 
Zhang S, Ma K, Chen L (2003) Response of photosynthetic plasticity of Paeonia suffruticosa to changed light environments. Environ. Exp. Bot. 49:121133.
Zouni A, Witt HT, Kern J, Fromme P, Kraub N, Saenger W, Orth P (2001) Crystal structure of photosystem II from Synecococcus elongates at 3.8 A resolution. Nature 409:739-43. 